\title{
“And why may not I go to College?" Alethea Stiles and Women's Latin Learning in Early America
}

\author{
THEODORE R. DELWICHE
}

\begin{abstract}
Presented here for the first time are the letters of a young, little-known American woman, Alethea Stiles (1745-1784), to her learned cousin Ezra Stiles (17271795), the seventh president of Yale College. Brief and no doubt modest though these two English and one Latin letter may be, they provide an important point of entry into the women's world of classical education in early America. Increasingly, American classical receptionists are trying to look beyond the "founding fathers" and consider what the classics meant in early America for men and women alike. We might do well, however, to reconsider one of the long-standing premises of reception research: that women interacted with the classical past largely outside of Latin and Greek texts and wrote little in the ancient languages. Leveraging both her knowledge of Roman history and the Latin language itself, Alethea advocated for admissions into Yale College over two centuries before the institution would welcome women. Though this attempt would not succeed, the presence of Alethea in the historical record demonstrates that even institutions that explicitly excluded precocious young women still include them in the archives.
\end{abstract}

In the fall of 1754, nine-year-old Alethea Stiles penned a letter to her cousin and then tutor at Yale College, Ezra Stiles. Alethea thanked Stiles for the "pretty presents" he had sent her, but had a bone to pick with her learned relative:

My brother is glad of the book you sent him and says he will learn it. He talks a great deal about going to the college. And why may not I go to colleg[e]? For my father says one Jenny Cameron put on jacket and breeches and was a good soldier. And why may not I do so and live at college? I have learned Eutropius and am now in Justin. ${ }^{1}$

With her reference to Jenny Cameron, a Scottish woman rumored to have taken part in the Jacobite Rising of 1745, the younger cousin highlighted

1 Alethea Stiles to Ezra Stiles, 7 October 1754. New Haven, CT, Yale University, Beinecke Rare Book and Manuscript Library, Ezra Stiles Papers, Gen MSS 1475, Box 11, Folder 899. 
the precedent for transcending traditional gender roles. ${ }^{2}$ Alethea kept at it. When her brother and sister died just years later, she found solace in sending Ezra digests of her reading in Roman history: "my tender father keeps me to my books \& I have once more gone throu Eutropius and am now in Cornelius of Nepos. my father has made a short History from Eutropius by way of Quest and Answer and set me to get it by hart."3 And, in a remarkably adroit move at the age of eleven, she passed along an embroidered pocketbook with an accompanying original Latin letter. Presented here for the first time are all of young Alethea's letters to Ezra Stiles. Brief and no doubt modest though it may be, this corpus of epistles helps classical receptionists look beyond the "founding fathers" and consider what the classics meant in early America for men and women alike.

Early American women were not supposed to learn Latin, or so we at least believe. Both opponents and proponents of women's education in early national America agreed on this: the study of the classics had been the traditionally distinguishing factor of men's education. ${ }^{4} \mathrm{~A}$ case in point is the young John Adams (1735-1826), who famously warned his nieces in 1761: "I would not have you Pedants in Greek and Latin nor the Depths of science, nor yet over fond to talk upon any Thing." 5 To delve into classical history and culture was acceptable, but to start learning the languages was a risky endeavor.

To be fair, there were some means for early American women to engage with the classical past, especially in the rising salon, coffeehouse,

2 For one such depiction, see the broadside "Miss Jenny Cameron in a Military Habit", National Library of Scotland, Jacobite prints and broadsides, 133, Blaikie.SNPG.15.3 A. And, for a wider discussion: C. Martin, "Female Rebels': The Female Figure in AntiJacobite Propaganda", in A.I. Macinnes, K. German, L. Graham (ed.), Living with Jacobitism, 1690-1788: The Three Kingdoms and Beyond (London, 2014), 85-99.

3 Alethea Stiles to Ezra Stiles, 22 December 1755. New Haven, CT, Yale University, Beinecke Rare Book and Manuscript Library, Ezra Stiles Papers, Gen MSS 1475, Box 11, Folder 900.

4 L. Kerber, Women of the Republic: Intellect and Ideology in Revolutionary America (Chapel Hill, 1980), 217-222.

5 John Adams, Diary [Jan. 1761], 42. Adams Family Papers: An Electronic Archive. Massachusetts Historical Society, https://www.masshist.org/digitaladams/archive/doc?id=D6. 
and print culture of the eighteenth century. ${ }^{6}$ To maneuver deftly through these places of polite conversation, however, was an intellectual tightrope act that women had to master early, or risk scorn later. As Caroline Winterer explains: "Women now had to acquire, without formal schooling, a grasp - however tenuous - of the ways and means of people who had lived two thousand years before. But they had to do so within narrow boundaries. ... [A woman] should have enough learning to take an interest in her companion's conversation but not be so learned as to surpass his grasp of the subject." scholars like Winterer have explored the varied ways that early American women still managed to creatively engage with the classical tradition. ${ }^{8}$ But we might do well to reconsider one of the fundamental premises of this type of research: that women interacted with the classical past largely outside of Latin and Greek texts and wrote little in the ancient languages.

Alethea Stiles is just one example of an overlooked, young American woman who self-consciously strove to replicate the education of the grammar school at home. ${ }^{9}$ There are yet others. Take Lucinda Foote as another case in point, a 12-year-old girl who passed the Yale entrance examination in 1783 with flying colors, receiving a makeshift Latin (non)degree from Ezra Stiles attesting to her skills and affirming that

${ }^{6}$ Brief mentions to classical learning have been made in intellectual histories of early American women. See S. Fatherly, Gentlewomen and Learned Ladies: Women and Elite Formation in Eighteenth Century Philadelphia (Bethlehem, PA, 2008); A. Ousterhout's The Most Learned Woman in America: A Life of Elizabeth Graeme Fergusson (University Park, PA, 2010); and L. Glover, Eliza Lucas Pinckney: An Independent Woman in the Age of Revolution (New Haven, 2020).

7 C. Winterer, "The Female World of Classical Reading in Eighteenth-Century America", in H. Brayman Hackel, C.E. Kelly (ed.), Reading Women: Literacy, Authorship, and Culture in the Atlantic World, 1500-1800 (Philadelphia, 2008), 105-123, at 107.

8 C. Winterer, The Mirror of Antiquity: American Women and the Classical Tradition, 1750-1900 (Ithaca, 2009). Considerable attention has also been paid to eighteenth-century poet Phyllis Wheatley's education and use of the classics in her poetry. Among others, see: E. Greenwood, "The Politics of Classicism in the Poetry of Phyllis Wheatley", in R. Alston, E. Hall, J. McConnell (ed.), Ancient Slavery and Abolition: From Hobbes to Hollywood (Oxford, 2011), 153-175; P. Toscano, "Epic Regained: Phillis Wheatley's Admonitory Poetics in the Little Columbiad", Classical Receptions Journal 13.2 (2021), 178-211; and D. Waldstreicher, "Ancients, Moderns, and Africans: Phillis Wheatley and the Politics of Empire and Slavery in the American Revolution", Journal of the Early Republic 37.4 (2017), 701-733.

9 On the colonial New England grammar school, see T. Keeline, S. McManus, "Benjamin Larnell, the Last Latin Poet at Harvard Indian College", Harvard Studies in Classical Philology 108 (2015), 621-642; and T. Delwiche, "An Old Author in the New World: Terence, Samuel Melyen, and the Boston Latin School c. 1700", The New England Quarterly 92.2 (2019), 263-292.

Humanistica Lovaniensia 71.2 (2021), 305-318 
"were it not for the reason of her sex, she would be fit to be admitted as a student at Yale university in the recent class." 10 At a dinner party of Ezra Stiles's, one fellow minister also marveled at Lucy Ellery Channing, a woman "of very uncommon literary accomplishments" who "not only reads but speaks French, Latin, and Greek, with great ease."11 Outside of Yale, at nearby Harvard, a teenage Eloise Richards Payne (1787-1819) is said to have undergone examination in Latin and impressed the faculty at the time. ${ }^{12}$

One eighteenth-century history of Connecticut even proclaimed that the region contained "not a few" women "so well skilled in Greek and Latin as often to put to the blush learned gentleman." 13 We can be cautiously optimistic that there may be some germ of truth to this assessment. Like the famed case of the Stephanus printshop in sixteenth-century France, where men and women of all ages and nationalities shouted at each other in Latin, Eliza Buckminster Lee remembered of her late father in eighteenth-century Connecticut: "He was in the habit of addressing familiar questions and simple household orders to his daughters in Latin, and then of explaining them or giving them the dictionary to find them out."14 Beyond Connecticut, in Philadelphia, the daughters of George Keith, a famously learned eighteenth-century Quaker, also come to mind,

10 Ezra Stiles (1727-1795, Yale 1746). Testimonial concerning the educational achievements of Lucinda Foote, 1783 December 22, Yale, New Haven, CT, University Library Manuscripts and Archives, MVP \#846A, Yci $818+$ C8. "Vobis notum sit: quod Dominam Lucindam Foot Aetat[is] 12. Examine probavi, eamque in linguis edoctis, Latina et Graeca, laudabilem progressum fecisse; eo ut familiariter et reddidisse \& tractasse reperivi, tum verba tum sententias, alibi in Aeneide Virgilii, in selectis Ciceronis Orationibus, et in Graeco Testamento. Testorque omnino illam, nisi Sexus ratione, idoneam ut in classem Recentium in Universitate Yalensi Alumna admitteretur. Datum e Bibliotheca collegii Yalensis, 22 die Decembris, Anno Salutis MDCCLXXXIII. Ezra Stiles President." In the above quotation, reperivi stands in for the perfect tense repperi, which, given its function in the result clause, likely should have been construed as reppererim. For more on Ezra Stiles's thoughts on women's education, see C. Lutz, "Ezra Stiles and the Education of Women", Yale University Library Gazette 71 (1996), 49-55.

11 Manasseh Cutler, William Parker Cutler, and Julia Perkins Cutler, Journals and Correspondence of Rev. Manasseh Cutler vol. 1 (Cincinnati, 1888), 219. Meeting with Miss Channing seems to become something of a ritual, as Cutler notes also conversing with later in the year when he visited Ezra Stiles again.

12 Gabriel Harrison, John Howard Payne, His Life and Writings (Philadelphia, 1885), 14.

13 S. Peters, General History of Connecticut (New York, 1877), 224. Reference courtesy of C. Holliday, Woman's Life in Colonial Days (Mincola, NY, 1999 [reprint of 1922 edition]).

14 E. Buckminster Lee, Memoirs of Rev. Joseph Buckminster, D.D. And of His Son, Rev. Joseph Stevens Buckminster (Boston, 1851), 14. 
as they were reportedly remarkable in their classical education. ${ }^{15}$ So too was Margaret Wythe, granddaughter of George Keith and mother to judge and statesmen George Wythe, who marveled at his mother's Latin fluency in both speaking and writing. ${ }^{16}$ In New Jersey, Rachel van Dyke was particularly adamant about keeping up her Latin studies, consistently writing reminders to herself in her diary: "I must not neglect my Latin...for both my pride and my desire to acquire a knowledge of it prompt me to perseverance. If I neglect it, it will be said by those who now secretly laugh and sneer at my ambition - 'Ah! I knew it would be so. I knew she would never go through with it. She undertakes and intends to do wonders - yet performs but trifles." 17 With time, Rachel even noted fellow schoolgirls who began studying Latin too, providing solace to the apparent "sneers which are thrown upon such presumption in a female."18

As with anything, some of these first-hand accounts or late-life reminiscences may prove more nostalgic than true. Evidently, the most reliable means to get at the heart of women's learning is to probe the archives for records of women themselves. Here, the university archive has surprisingly much to offer. For sisters never simply said goodbye to their brothers when they entered college. Instead, they maintained frequent and often quite extensive correspondence that touched on all aspects of domestic and intellectual life.

When he was a student at Harvard in the mid-eighteenth century, Robert Treat Paine tested out his oratorical performances with his sister, Eunice, before delivering them to his student society. ${ }^{19}$ Later, in the earlynineteenth century, Sarah Ann Ripley provided more than just emotional support to her brother enduring a bout of melancholy at Harvard: Ripley gave detailed reports on her readings in Greek and Latin literature, as well as the learned periodicals of the day. Indeed, Ripley was well prepared to do so. With some trepidation, so the legend around Ripley at least goes,

15 On George Keith's Latin, see M. Birkel, C. Northrop, Quakeriana Latina: Quaker Texts in Latin from the 1670s (Leiden, 2020).

16 T. Hunter, "The Teaching of George Wythe", in S. Sheppard (ed.), The History of Legal Education in the United States: Commentaries and Primary Sources (Pasadena, 1999), 140.

17 Lucia McMahon, Deborah Schriver (ed.), To Read My Heart: The Journal of Rachel van Dyke, 1810-1811 (Philadelphia, 2000), 31 [May 29, 1810].

18 Ibid., 53 [Jun. 20, 1810].

19 Robert Treat Paine to Eunice Paine, 20 Mar. 1748, in S.T. Riley, E.W. Hanson (ed.), The Papers of Robert Treat Paine, vol. 1 (1746-1756), (Boston, 1992), 30-31; Robert Treat Paine, Essays Presented to the Phinphilenici [sic] Club at Harvard, 1748, Robert Treat Paine Papers, Massachusetts Historical Society, P-392, reel 19, case 43. 
she summoned the courage at a young age to ask her father if she could study Latin. The paternal reply allegedly combined surprise with enthusiasm: "Latin! A girl study Latin! Certainly. Study Anything you like."20 Folklore aside, Ripley evidently pursued language instruction in earnest. Her letters, most of them unpublished and unexamined, vividly chronicle her voracious intellectual appetite. Ripley kept up to date on the most prominent learned magazines and periodicals of the day, offering approval and censure in equal measures (in June 1820, she sullenly wrote: "We have another number of the Edinburgh [Review] but it is dull"). ${ }^{21}$ Rarely was Ripley reticent or hesitant to critique classical style: "I have just finished the Andria of Terence, there is interest enough in the plot to make one want to know how it will come out, which you know is not very often the case in any of the Greek dramas." 22 So much for Adams's advice, as this was a woman proud of her learning and even prouder to offer her assessment of classical literature!

Granted, part of the reluctance to consider sources such as these has less to do with gender and more with the simple fact that they are often in a classical tongue or laden with references to Latin and Greek literature. Until relatively recently, historians of classical reception in the American context have declined digging into the mounds of Neo-Latin and NeoGreek manuscripts that clutter the colonial archive. ${ }^{23}$ Now, more than ever, might be the time to revisit our widespread assumptions about women's access to classical education in early America.

Indeed, there is a certain, reassuring irony to the case of Alethea's letters. At this point, it has become a tired truism that archives are incom-

20 G. Bradford, Portraits of American Woman (New York, 1919), 36. See also J. Goodwin, The Remarkable Mrs. Ripley: The Life of Sarah Alden Bradford Ripley (Boston, 1998), 5-26.

21 Sarah Ripley to Daniel Bradford, 13 June 1820. Cambridge, MA, Radcliffe Schlesinger Library, Papers of Sarah Alden Ripley, 1806-1867, MC 180, Box 109.

22 Sarah Ripley to Daniel Bradford, 7 Dec. 1819. Cambridge, MA, Radcliffe Schlesinger Library, Papers of Sarah Alden Ripley, 1806-1867, MC 180, Box 109.

23 Among others, T. Keeline, S. McManus, "Aenigma omnibus: The Transatlantic Humanism of Zinzendorf \& the Early Moravians", Journal of the Warburg \& Courtauld Institutes 82 (2019-2020), 315-356; T. Delwiche, "Vilescunt in dies bonae literae: Urian Oakes and the Harvard College Crisis of the 1670s", Lias: Journal of Early Modern Intellectual Culture and its Sources 46 (2019), 29-58; and S. Hale, "John Beveridge, the Neo-Latin Horatian Ode and the Narrative of British Colonialism in Eighteenth-Century North America", International Journal of the Classical Tradition 27 (2020), 554-580. Treatment of Neo-Latin texts, including those authored by women, has been much better in early modern Europe. See J. Stevenson, Women Latin Poets: Language, Gender, and Authority from Antiquity to the Eighteenth Century (Oxford, 2005). 
plete. As much as they include, they almost invariably exclude. And yet here we see that an institution that explicitly excluded this precocious young woman includes her in the archives. The methodological point here is that the institutional archive, when probed beyond the plethora of mundane university happenings, opens up unexpected doors of research. We know next to nothing about Alethea Stiles beyond these letters brought to light in this article and a single existing piece of her needlework. ${ }^{24}$ It is the archive, as fractured and problematic as it is, that gives voice to Alethea. To get at more stories like this involves sifting through the archival dross for the gold. We have done well to remember Ezra Stiles, one of the most learned men in eighteenth-century America, and his engagement with the classical past. ${ }^{25}$ In the end, it is worth also remembering Alethea, and finding others like her.

Yale University teddy.delwiche@yale.edu

24 The only other source from Alethea's hand is a 1762 piece of embroidery. See C. Huber, S. Huber, S. Schoelwer, A. Lansing, With Needle and Brush: Schoolgirl Embroidery from the Connecticut River Valley, 1740-1840 (Old Lyme,CT, 2011), 54, Plate 32. More writings exist of Alethea's father, Abel Stiles. See Abel Stiles, Sermons, in New Haven, CT, Yale University Divinity School Library, Andover Newton Miscellaneous Personal Papers Collection, RG 295, b. 153, f. 1-21.; and Abel Stiles, Letters, in New Haven, CT, Beinecke Rare Book and Manuscript Library, Yale University, Ezra Stiles Papers, Gen MSS 1475, Box 14, Folders 1109-1135. Very brief mentions of Alethea are found in these letters, usually attesting to her health or illness. In 1757, she was apparently still on good terms with Ezra, as Abel reports: "our Daughter desires to make you a visit and tarry a few months, but we cant yet spare her from home." Abel Stiles to Ezra Stiles, 9 June 1757, Abel Stiles, Letters, in Yale University, Beinecke Rare Book and Manuscript Library, Ezra Stiles Papers, Gen MSS 1475, Box 14, Folders 1126.

25 E. Morgan, The Gentle Puritan: A Life of Ezra Stiles, 1727-1795 (Chapel Hill, 1962); S. McManus, "Classica Americana, An Addendum to the Censuses of Pre-1800 Latin Texts from British North America", Humanistica Lovaniensia 67.2 (2018), 421-461; and T. Delwiche, "Ezra Stiles and North America in the Early Modern Republic of Letters", Modern Intellectual History (2021), first-view. 


\section{Appendix: Stiles' letters}

Clear abbreviations are expanded below, but otherwise editorial intervention is minimal. Alethea rarely used punctuation, but her writing is uniformly clear. The one Latin letter includes my own translation afterwards. The Beinecke Library has previously digitized these letters, pictures of which follow at the end.

\section{Alethea Stiles to Ezra Stiles, 175408 07, Yale University, Beinecke Rare Book and Manuscript Library, Ezra Stiles Papers, Gen MSS 1475, Box 11, Folder 899 (fig. 1).}

Received Oct. 13, 1754

Answered Oct. 31, 1754

For Mr. Ezra Stiles

Tutor of the College in New Haven

Kind Sir,

My brother my little sister and I have the pretty presents you sent us and we are all dreadful glad to find that our kindsman so far from us should remember such children as we; we all send you our thanks my father says the bits of silver are the art of Spain but the shells the nature of Hispaniola my brother is glad of the book you sent him and says he will learn it he talks a great deal about going to the college and why may not I go to colleg[e] for my father says one Jenny Cameron put on jacket and breeches and was a good solider and why may not I do so and live at college I have learned Eutropius and am now in Justin we all send our love to you sir and I write my name to shew you that I am your little cousin.

Woodstock [CT] October the $71754 \quad$ Alethea Stiles 


\begin{abstract}
Alethea Stiles to Ezra Stiles, 175512 22, Yale University, Beinecke Rare Book and Manuscript Library, Ezra Stiles Papers, Gen MSS 1475, Box 11, Folder 900 (fig. 2-3).
\end{abstract}

Received Jan. 17, 1756

Miss Alethea Stiles Dec. 1755

For the Reverend

Mr. Ezra Stiles

at Newport [RI]

Reverend Sir

Woodstock December 221755

In your letter to my honoured father you made a kind mention of your cousin Alethea who is much obliged to you for it while I was at Lebanon I was busie with my needle and did but little in reading or writing Since I came home my tender father keeps me to my books \& I have once more gone throu Eutropius and am now in Cornelius of Nepos my father has made a short History from Eutropius by way of Quest and Answer and set me to get it by hart in which short history I have learned the following things viz that the Roman Empire was like a little child in its begining Romulus built the city Rome on the Palatine mount he formed the Senate and died in the $37^{\text {th }}$ year of his reign the next king was the famous [2] Numa Pompilius who made good laws and appointed religious worship such as it was Tullus Hostilius the next king put the soldiers in order added mount Celius to Rome and at last was killed with Lightning Martius Ancus the next king made a wall round the City and made a bridge over the River Tiber runing throu the City Tarquinius Priscus the next king was the first who had a Triumph he built the Capitol and increased the Senate there were 2 kings more viz Servius Tullus and Tarquinius Superbus. After the kings came the consuls there were 2 of them at a time and chosen every year but I have time to write no more now you will easily guess I could not send you this had not my father helped me. your Pocketbook shall be sent when it is finished I am with due regards your little cousin who live while my brother and sister are dead - Alethea Stiles 


\section{Alethea Stiles to Ezra Stiles, 175603 01, Yale University, Beinecke Rare Book and Manuscript Library, E1475, Box 11, Folder 901.} (fig. 4).

For the Reverend

Mr. Ezra Stiles

Answered 21 May 1756

Newport [RI]

Domine Literate, Reverende, prae ceteris germanis peramande ${ }^{26}$. Haec theca nummaria, quam acu pinxi, pro munere tibi offertur, a parvula patruele. Alethea Stiles

P.S. Vides, qua ratione, rem acu tetigi ${ }^{27}$

Woodstock [CT] March the $1^{\text {st }} 1756$.

Editor's translation:

Learned and revered master, beloved before all other relatives. This pocketbook, ${ }^{28}$ which I decorated with needlework, is offered to you as a gift from your little cousin. Alethea Stiles. P.S. You see how knowingly I hit the nail on the head.

26 Peramandus is not attested to in classical literature, but evidently an intensifying form of Alethea's own devising that showcases her utmost love to her cousin.

27 Alethea's use of rem acu tangere (see Plaut. Rud. 1306) - to hit the nail on the head, in English idiom - is particularly apt, for the phrase alludes both to her needlework (picking up on acu pinxi, earlier in her letter) but also more generally to the act of giftgiving, letter and all. Here was a precocious young woman who cleverly used her mastery of needlework to showcase her Latin learning. Gendered expectations - sewing for girls but parsing for boys - thus melt and merge into one in Alethea's epistle. Deservedly so, Alethea highlighted this shrewd accomplishment.

28 Given that Alethea referred to the present as a "pocketbook" rather than a "wallet" in the previous letter, I have decided to translate theca nummaria thus. This usage of pocketbook signifying wallet is an Americanism. See "Pocketbook, n. and adj.", 2a, in Oxford English Dictionary Online, https://www.oed.com/view/Entry/146407?redirected From=pocketbook (accessed December 14, 2021). 
Rind 19

My forothermy little Sifter and Shave the preth prifonts you fent us and we are all dreadful glao to fino that our king mann fofarfiomeras fhould seinember fuch hildricaras we, weall feno you eur thanhs my father says the bits of Silverare the art of sparis but the. Shalls the nature of Jitif

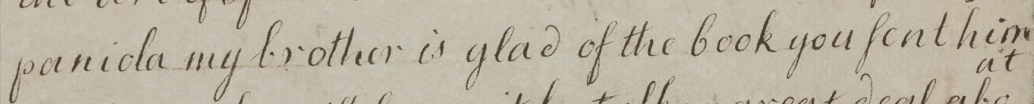
and says hic will learn it he talksagreat ocal abo going to y college anow why mannot la goto colley teo foring fatherisers one genny Cameronput on Gaeketand brecehesang was agood solioerane: and wherrey.net oc fo and lizeat colleqc4 havelearnco \&utropius andam now fn fuftin. we all pend ourlove toyou, fre and firite iny. nameteflecw youllat yane yourlittle Gufin Woodflock octobongy iysin Aletleca stilis tis:

Fig. 1: Alethea Stiles to Ezra Stiles, Gen MSS 1475, Box 11, Folder 899. Image: The Beinecke Library. 
Reverend Sis.

\section{Weodfleck Decem 29}

In your Letter to my honoured father you maded kind mintoionof your Gufin Althea whois much obliged to you for it while \& was at Lebainon mas bufie with my Sradle and did but little it veading or writing Since I Came home my. Inder fathor kups meto iny boaks \&l f haveonce - more gonethreus Culropius andam now sn Cornele us Srepos my futher hew meded Storl Hiftory from Eatropius by wary of 2ueft and Anfwer and set me to yet it by have In wich Short hiftory Shave Learned the following thingh 2 ir Shat the Roman Empire was like a litte (Fild in hits beqining Romulus built the (ily Rosne on the Palatine mount he for med the Senate and died Sn if'

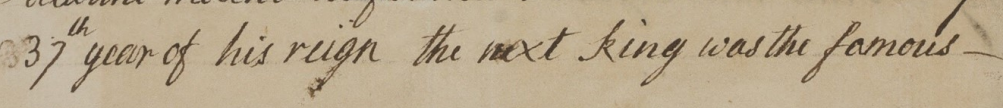

Fig. 2: Alethea Stiles to Ezra Stiles, Gen MSS 1475, Box 11, Folder 900. Image: The Beinecke Library. 
Numa Sompixses who made good lavis and appointe rete gious worfhip Such as it wos Sullus. Hoftilius ther next king put the Soldiess in onder added mount Clius to Rome andat laft war Rilled with Lightning Martius Ancew the next king made a crall round the ity and made a bridge over the Riven Siber. vuning thrs the (ity Sarquinius Srifcus the next King was the firgs. whohal a Iriumph he built the Capild and gnoreafed the fenate. there were 2 kings more viz Sorvius Stulleus. and Sarquinius Superbus. After the kings farnethe confuls thesce were of them at atime and ho fen exery year but 9 herve tine to write no morcnow you will cafley quef. 9 fould not tond you this had not my fallin helpod me. your. Socketbook Shall be Sont when it is finifted

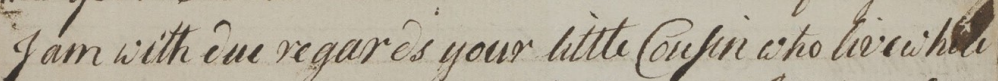
my brothor and Sifter are ceads. Alethea fliles

Fig. 3: Alethea Stiles to Ezra Stiles, Gen MSS 1475, Box 11, Folder 900. Image: The Beinecke Library. 


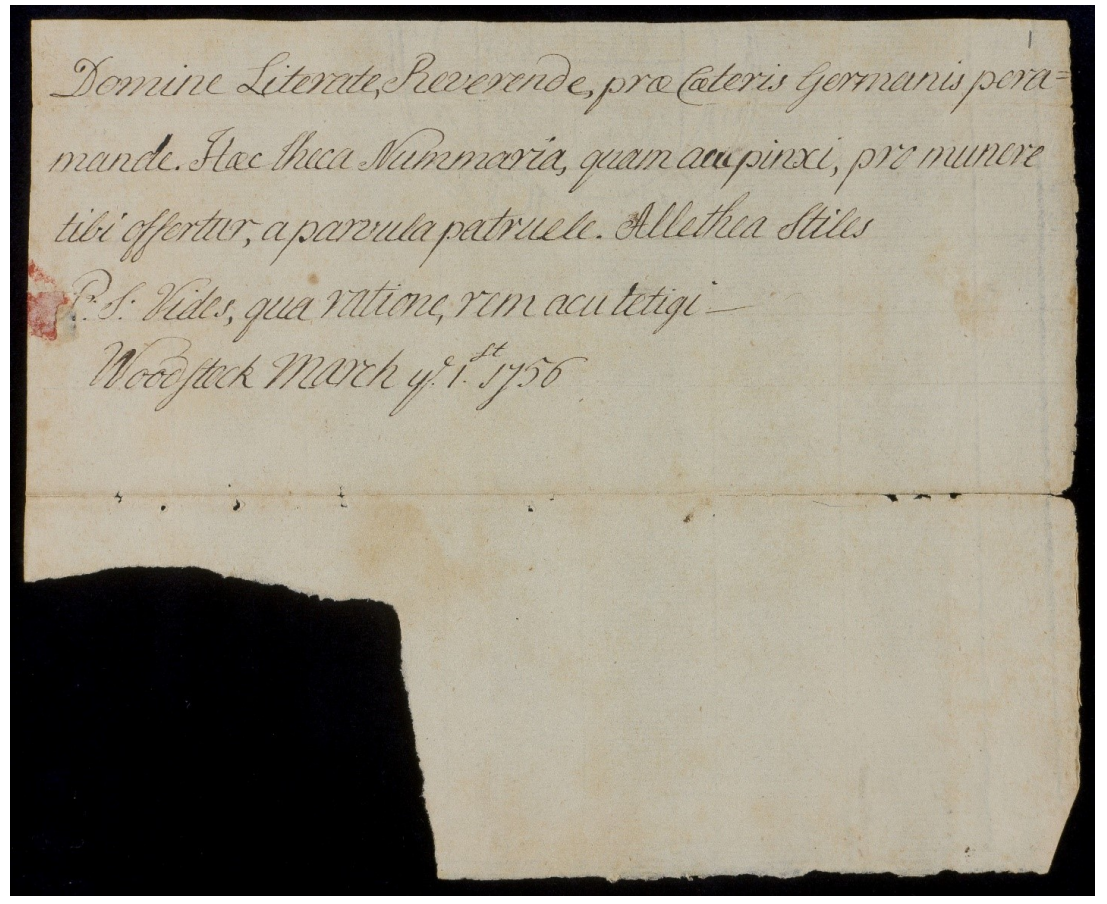

Fig. 4: Alethea Stiles to Ezra Stiles, Gen MSS 1475, Box 11, Folder 901. Image: The Beinecke Library. 